\title{
Coordinated response to inadvertent introduction of pathogens to California restoration areas
}

\author{
Growers, regulators and native plant restoration experts are together trying to reduce the spread \\ of more than 25 new Phytophthora taxa
}

\author{
Susan J. Frankel, Plant Pathologist, Ecosystem Function and Health, USDA Forest Service, Pacific Southwest Research Station \\ Janice M. Alexander, Forest Health Program Coordinator, UC Cooperative Extension Marin County \\ Diana Benner, Owner, Watershed Nursery \\ Alisa Shor, Director of Park Nurseries, Golden Gate National Parks Conservancy
}

\section{Phytophthora tentaculata was cultured from the roots of this nearly dead sticky monkey flower (Diplacus aurantiacus) 2 years after outplanting in a restoration area in Alameda County.}

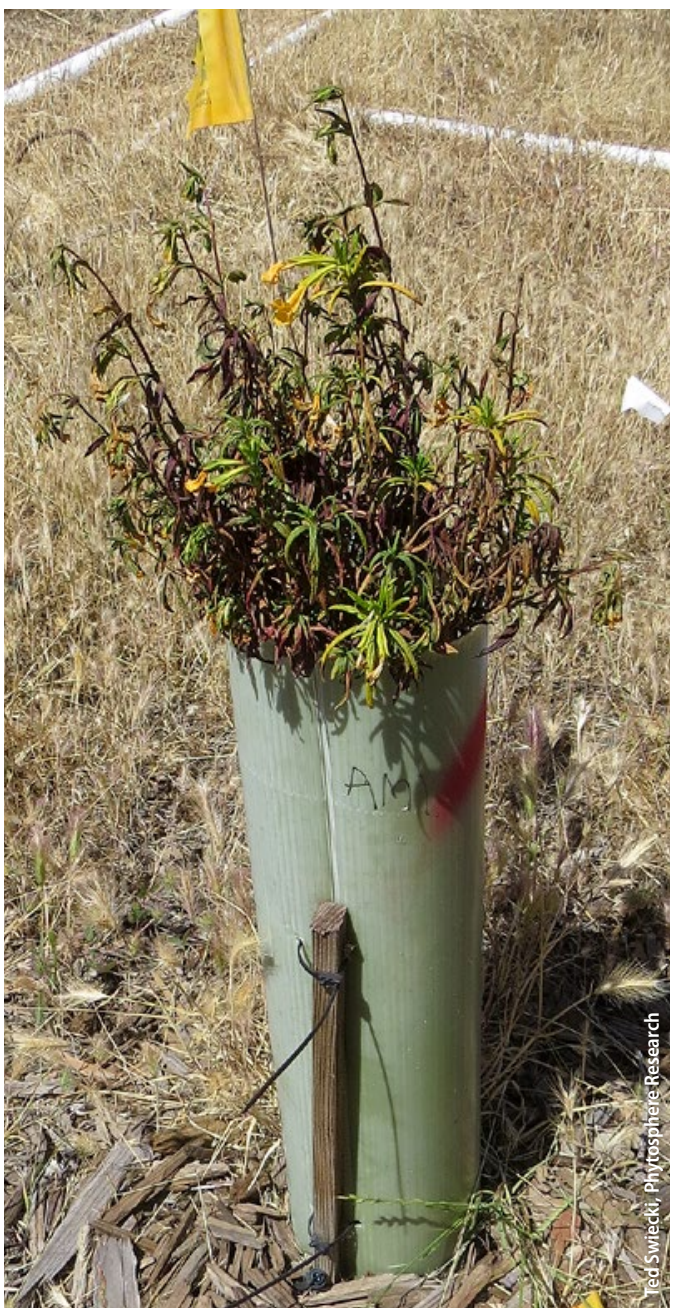

n 2012, a plant pathogen known as Phytophthora tentaculata was discovered on sticky monkey flower (Diplacus aurantiacus) at a native plant nursery in Monterey County (Rooney-Latham and Blomquist 2014). Subsequently — in a development that stunned restoration ecologists as well as growers at native plant nurseries - evidence emerged that $P$. tentaculata, $P$.

cactorum and other new or new hybrid Phytophthora species had been unintentionally but extensively introduced into restoration areas in the greater San Francisco Bay Area (Garbelotto et al. 2018, page 208 in this issue). These soilborne plant pathogens, as they move from native plant nurseries to restoration sites via planting stock, potentially undermine the very purpose of restoration projects. That is, they degrade rather than enhance habitat - not only causing plant mortality but also threatening ecological investments intended to improve habitat for vulnerable species such as coyote ceanothus (Ceanothus ferrisiae), California tiger salamanders (Ambystoma californiense), California red-legged frogs (Rana draytonii) and mission blue butterflies (Aricia icarioides missionensis).

In 2015, in an effort to protect sensitive habitats and restoration sites against
Phytophthora and other introduced plant pathogens, we created an organization called the Phytophthoras in Native Habitats Work Group and invited any interested parties to join. The Work Group's aim is to minimize the spread of Phytophthora pathogens in restoration sites and native plant nurseries by coordinating a comprehensive, unified program entailing management, monitoring, research, education and policy. The Work Group - modeled after the California Oak Mortality Task Force - builds consensus; provides technical assistance to stakeholders such as government agencies, nursery growers and nonprofit organizations; develops strategies and techniques to support adaptive integrated pest management programs to address Phytophthora species in restoration areas; and identifies funding needs and available resources to protect wildlands and assist the restoration industry in its efforts to contain Phytophthora.

\section{The problem}

When P. tentaculata was discovered in Monterey County in 2012, it was the first time the pathogen had been detected in the United States. P. tentaculata was subsequently detected on toyon (Heteromeles arbutifolia), coffeeberry (Frangula californica) and sage (Salvia spp.) in nurseries and at restoration sites in several California counties (Rooney-Latham et al. 2015). Further investigations detected P. quercina - a microbe with high potential to damage U.S. environmental and economic interests (Swiecki and Bernhardt 2017) - on a planted valley oak (Quercus lobata) in a restoration area in San Jose (Santa Clara County). As with $P$. tentaculata, this was the first time P. quercina had been detected in the United States. A survey of native plant nurseries and restoration areas, conducted from 2014 through 2016, identified well over 25 Phytophthora taxa in the nurseries or in plantings that originated from the nurseries (Rooney-Latham et al. 2017), along with at least 70 new associations between Phytophthora and native plant species. 
Phytophthora cinnamomi introduced into native habitats can kill susceptible species, such as the giant chinquapin (Chrysolepis chrysophylla) visible in this photo taken in the Oakland Hills (Alameda County). Pallid manzanita (Arctostaphylos pallida) mortality due to P. cinnamomi infection is also present in this stand.
Two decades earlier, the sudden oak death pathogen (P. ramorum) had emerged from nurseries to create an uncontrollable epidemic of wildland plant disease. Now, detections of Phytophthora sparked concern that, once again, invasive species could travel the nursery-to-wildland pathway to cause an inadvertent but uncontrollable epidemic. The sudden oak death pathogen had been introduced to California and Oregon on ornamental nursery stock, most likely rhododendrons or camellias. It then moved via windblown rain into adjacent forests, taking hold in several areas along the Pacific coast and killing millions of tanoaks (Notholithocarpus densiflorus) and coast live oaks (Quercus agrifolia) (Rizzo et al. 2002). The spread of the oak pathogen demonstrated how, when container plants are transported, pathogens such as Phytophthora can travel long distances and proliferate across landscapes (Croucher et al. 2013; Goss et al. 2009; Grünwald et al. 2012). Once an area is contaminated, it is difficult or impossible to eradicate the pathogen and to restore lands (Goheen et. al 2017; Kanaskie et al. 2017).

\section{The response}

Some land managers, in response to soilborne Phytophthora introductions, suspended plantings, cancelled orders of nursery stock or invested millions of dollars in solarization treatments to clean up contaminated sites. But such measures achieved only partial eradication (Hillman et al. 2017; Lyman et al. 2017) - and in any event, neither discontinuation of restoration planting nor switching to direct seeding represents an ideal long-term approach to Phytophthora prevention. Many benefits of restoration are foregone or significantly delayed when nursery stock is not used.

The Work Group has pursued a collaborative approach to protecting native plant habitats. Participants - growers of native plants, vegetation managers connected with water districts and open space areas, restoration consultants, plant pathologists, plant health regulators and environmental regulators - have established an interdisciplinary process for developing best management practices regarding production at restoration nurseries, planting at restoration areas and maintenance of sites. The group has produced guidance that can help environmental regulators reduce the risk of Phytophthora spread (the guidance involves altering certain elements of restoration design and instituting changes to regulators' criteria for success). The group also has organized a number of symposia and trainings and has posted key Phytophthora information on the internet

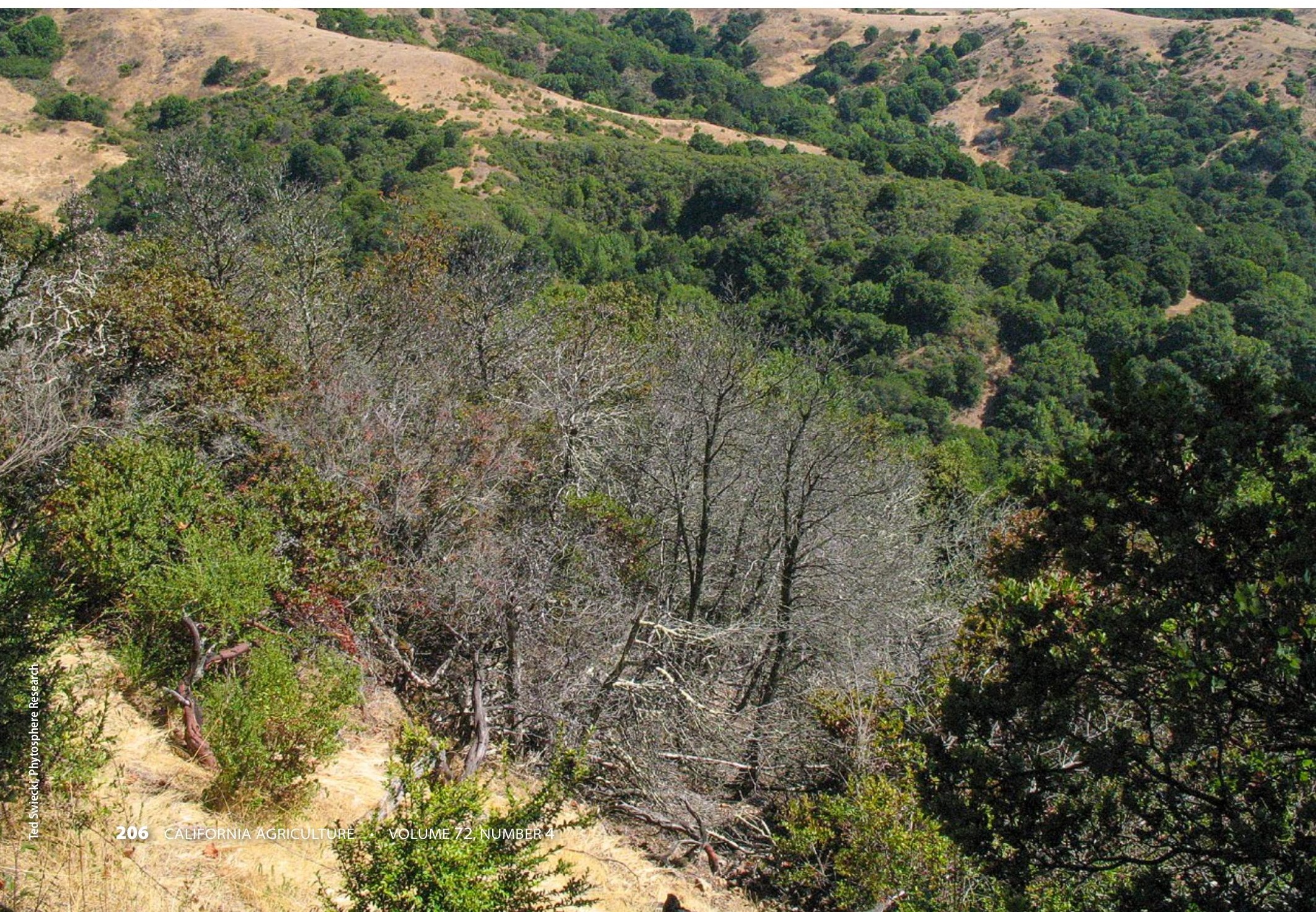


(calphytos.org). Partly in response to the group's work, several prominent managers of restoration nurseries proactively redesigned their facilities, imposing strict phytosanitary measures to prevent Phytophthora spread; they then shared stories of their success in growing healthier plants, inspiring other nursery managers to create clean areas for stock production (Sims et al. 2018). Organizations - with the help of interns, staff or contracted workers - sampled their properties to better understand the incidence and distribution of pathogens. Regulators such as the Army Corps of Engineers are incorporating Work Group guidance into environmental assessments. Finally, researchers are actively working on novel diagnostic approaches, including the use of dogs to sniff out pathogens (Swiecki et al. 2018, page 217 in this issue).

Concurrently, the California Native Plant Society adopted a policy intended to prevent harmful pathogens from spreading out of native plant nurseries or spreading via plant sales by the society's chapters; the policy fosters the use of clean, native plant stock in all landscape and restoration plantings. In February 2017, State Senator Bill Dodd introduced SB 287, entitled "Habitat restoration: invasive species: Phytophthora pathogens," which would require the California Department of Fish and Wildlife to adopt regulations to minimize the risk associated with Phytophthora pathogens in plant materials used for habitat restoration projects authorized, funded or required by the state. The Work Group, to simplify compliance with and enforcement of the prospective regulations, is exploring a program for restoration nursery accreditation or certification, which could be incorporated into the bill. Meanwhile, the California Department of Food and Agriculture revised its pest risk ratings for several Phytophthora species; the new ratings enable county agricultural commissioners to take control actions if they deem them warranted.

\section{More to do}

Many native plant nurseries, by adopting systematic phytosanitary measures, have committed themselves to preventing pathogen introductions. Much work remains to be done before all restoration nurseries are operating at the highest standards, but we are heartened by the progress made thus far and by the coalition's enthusiasm about the work still to come. Potential sources of contamination, however, are not limited to native plant nurseries - nurseries of all types pose risks. Many experts therefore agree that risks surrounding Phytophthora species and other plant pathogens (Swiecki and Bernhardt 2017) should be factored into hazard assessments for all nursery stock. Restoration nurseries have implemented phytosanitary measures to protect the diversity and vitality of natural vegetation - but because interconnections between people and nature are forever increasing, such measures might deserve wider adoption. CA

\section{References}

Croucher P, Mascheretti S Garbelotto M. 2013. Combining field epidemiological information and genetic data to comprehensively reconstruct the invasion history and the microevolution of the sudden oak death agent Phytophthora ramorum (Stramenopila: Oomycetes) in California. Biol Invasions 15(10):2281-97. doi:10.1007/s10530-013-0453-8

Garbelotto M, Frankel SJ, Scanu B. 2018. Soil- and waterborne Phytophthora species linked to recent outbreaks in Northern California restoration sites. Calif Agr 72(4):208-15. doi:10.3733/ ca.2018a0033

Goheen EM, Kanaskie A, Navarro S, Hansen E. 2017. Sudden oak death management in Oregon tanoak forests. Forest Phytophthoras 7(1):45-53. doi:10.5399/ osu/fp.7.1.4030

Goss EM, Larsen M, Chastagne GA, et al. 2009. Population genetic analysis infers migration pathways of Phytophthora ramorum in US nurseries. PLOS Pathog 5(9):e1000583. doi:10.1371/ journal.ppat.1000583
Grünwald NJ, Garbelotto M, Goss EM, et al. 2012. Emergence of the sudden oak death pathogen Phytophthora ramorum. Trends Microbiol 20(3):131-8. doi:10.1016/j.tim.2011.12.006

Hillman J, Swiecki TJ, Bernhardt EA, et al. 2017. 31 flavors to 50 shades of grey: Battling Phytophthoras in native habitats managed by the Santa Clara Valley Water District. In: Proceedings of the Sudden Oak Death Sixth Science Symposium www.fs.fed.us/psw/publications/documents/psw gtr255/ index.shtm

Kanaskie A, Wiese R, Norlander D, et al. 2017. Slowing spread of sudden oak death in Oregon forests, 2001-2015. In: Proceedings of the Sudden Oak Death Sixth Science Symposium www.fs.fed.us/psw/publications/documents/psw gtr255/ index.shtml
Lyman G, Appel J, Ingolia M, et al. 2017. Steam, solarization, and tons of prevention: The San Francisco Public Utilities Commission's fight to contain Phytophthoras in San Francisco Bay Area restoration sites. In: Proceedings of the Sudden Oak Death Sixth Science Symposium. www.fs.fed.us/ psw/publications/documents/ psw_gtr255/index.shtml

Presley C. 2016. Preventing the spread of plant pathogens. SERCAL 2016 Technical Session, Society of Ecological Restoration - California, June 15, Tahoe. www.sercal.org/thelatest/2017/10/3/preventingthe-spread-of-plant-pathogens

Rizzo DM, Garbelotto M

Davidson JM, et al. 2002

Phytophthora ramorum as the cause of extensive mortality of Quercus spp. and Lithocarpus densiflorus in California. Plant Dis 86(3):205-14. doi:10.1094/ pdis.2002.86.3.205
Rooney-Latham S, Blomquist CL. 2014. First report of root and stem rot caused by Phytophthora tentaculata on Mimulus aurantiacus in North America. Plant Dis 98(7):996. doi:10.1094/ PDIS-09-13-1002-PDN

Rooney-Latham S, Blomquist CL, Soriano MC, et al. 2017. An update on Phytophthora species in California native plant nurseries and restoration areas. In: Proceedings of the Sudden Oak Death Sixth Science Symposium. www.fs.fed.us/ psw/publications/documents/ psw_gtr255/index.shtml Rooney-Latham S, Blomquist $\mathrm{CL}$, Swiecki T, et al. 2015. First detection in the US: New plant pathogen, Phytophthora tentaculata, in native plant nurseries and restoration sites in California. Native Plants J 16(1):23-7. doi: 10.3368/npj.16.1.23

Sims L, Tjosvold S, Chambers D, Garbelotto M.2018 Control of Phytophthora species in plant stock for habitat restoration through best management practices. Plant Pathol 2018 doi:10.1111/ppa.12933
Swiecki T, Bernhardt E. 2017. Phytophthora species in California restoration sites and wildlands: Ecology, distribution, dispersal, management. In: Phytophthora species in Restoration Nurseries, Plants, and Wildlands II, San Jose, May 18. www.suddenoakdeath.org/wp-content/ uploads/2016/04/03-SwieckiPhyt-WG-mtg-5-20171.pdf Swiecki TJ, Quinn M, Sims L, et al. 2018. Three new Phytophthora detection methods, including training dogs to sniff out the pathogen, prove reliable. Calif Agr 72(4):217-25 doi:10.3733/ca.2018a0026 